ESJ Humanities

\title{
Iconography as a Means of Reaching Political Power: A Case Study of Three Georgian Presidents
}

\author{
Giorgi Aptsiauri (PhD Student)
}

Grigol Robakidze University, Tbilisi, Georgia

Doi:10.19044/esj.2021.v17n9p1

Submitted: 08 August 2020

Accepted: 23 March 2021

Published: 31 March 2021
Copyright 2021 Author(s)

Under Creative Commons BY-NC-ND

4.0 OPEN ACCESS

Cite As:

Aptsiauri G. (2021). Iconography as a Means of Reaching Political Power: A Case Study of Three Georgian Presidents. European Scientific Journal, ESJ, 17(9), 1.

https://doi.org/10.19044/esj.2021.v17n9p1

\section{Abstract}

This paper focuses on analyzing the structure of political iconography as one of the methods to achieve political power. On this basis, the political iconography of three Georgian presidents is analyzed. In the modern world, the most important tool for politics and politicians is creating a political icon. Political iconography is directly connected with Christian iconography. It is widely known that in order to get the desired impact on the society, various forms and means of mass communication are used such as personal, social, visual, rhetoric, audio, and communication. Using them without creating iconographic image from politicians does not have any result. Political iconography reaches and mostly remains in the mind of the society, and this leads people to make their decision to support the politician who is a hero of the iconography. This fits the narrative, meaning, and common discourse of the society, which formed an iconographic image of the certain politician. After the collapse of the Soviet Union, a new type of political iconography of Georgia was born which is essentially different from the Soviet iconography. The political iconography of these three Georgian presidents is based on the narrative of creating a modern state. There is however a substantial difference between them. Zviad Gamsakhurdia created the political iconography of a savior, Edward Shevardnadze was seen as an iconic politician, and Mikheil Saakashvili was a creator of power and savior.

Keywords: Political Iconography, Iconographic Image, President, Society 


\section{Introduction}

The three presidents of Georgia used iconography as one of the methods of achieving success in the political arena. It is worthy to note that a politician should possess cultural resources to assure the society to follow him /her as a leader.

Zviad Gamsakhurdia, the first President of Georgia, is a son of the well-known Georgian writer Konstantine Gamsakhurdia. He was able to easily convince the society to follow him. This happened because, in those days, the whole population of Georgia was fed up with the idea that "good family roots" gives birth to a persuasive leader. Thus, this served Zviad Gamsakhurdia as the cultural resource.

The main cultural resource that Eduard Shevardnadze used to boast was the contacts he had with internationally known politicians throughout the world. On the other hand, Mikheil Saakashvili's cultural resource was based on pro-western oriented young generation coming to politics. This happened to be a universal discourse for the whole post-Soviet society at that time.

Before discussing iconography in details as one of the methods used to achieve success by the three Georgian presidents, it is important to explain the essence of iconography first and the political options hidden behind it. For this reason, the present study focuses on making an analysis of the political iconographic structure of the three Georgian presidents and the icon-fighting relation between them.

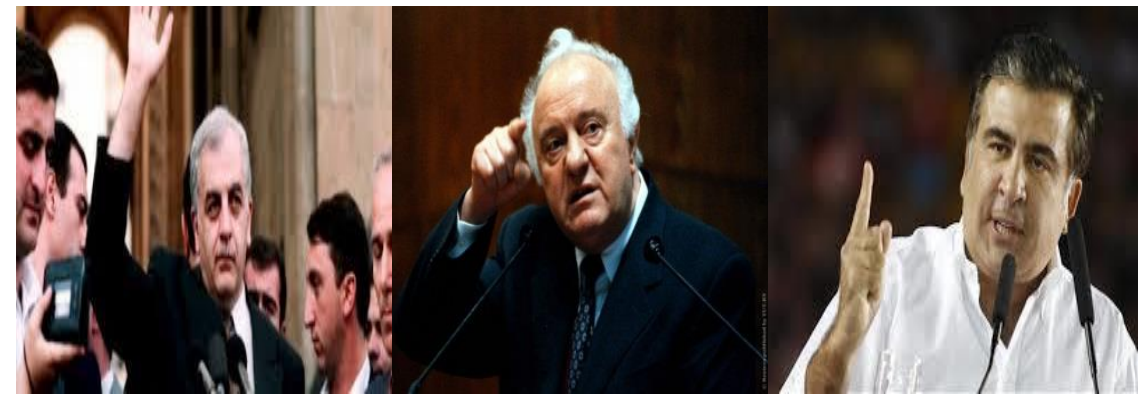

Picture 1. Political Iconographic Analysis of three Georgian Presidents

\section{Materials and Methods}

From the viewpoint of methodology, the iconographic analysis will be trusted. Here, the scientific works and publications about the biographies of the three presidents of Georgia will be used including the reference materials about iconography and iconographic images.

\section{Iconography}

An image is a visual element of identity, which is associated with the importance it holds. They are also used for specific purposes, mainly in public places. Images bear the function of a device and may be shaped in the mould 
of monuments, pictures, artefacts, and buildings. According to Hopkins, images communicate with people and create bonds between the real space and imagination. Moreover, this highlights the fact that they are part of the social and political history and demonstrate the essence of unity and continuity of people (Kaboudarahangi, 2012). Images have the essence of a non-specific context owing to which there are philosophical and cultural principles and beliefs beyond them. Images also attempt to draw the difference between the characteristics of cultural traits that serve as spatial metaphors of objects or places and form the system and identity of belief. There are two types of iconography: the one that creates images and the one that destroys them. This means that any kind of propaganda is simply unimaginable without iconography. Harold Lasswell characterizes propaganda as manipulation using solid collective models through significant symbols (Lasswell, 1951). $\mathrm{He}$ also believed that the main function of mass communication includes the following: observing the environment, correlating various parts of the society, and interrelating and conveying social and cultural heritage (Groys, 2014). In the contemporary world, the most powerful means for propaganda is the media. Some of the media products may be created solely for the purpose of serving propaganda without any other goals. This opinion is shared by Boris Groys who in his essays mentions the messages conveyed through the cinema products that have their influence over the society. Moreover, the attempts of the totalitarian regimes of the twentieth century to make the cinema magnificent and sublime had to face a failure with the only result, and the cinema was turned into a temporary weapon for propaganda (Groys, 2014). Nevertheless, Groys also states that the cinema may at its best stage show historical scenes demonstrating fights against images and not attempting to fight against them (Groys, 2014). People who are familiar with the field of media will capture the facts demonstrated by propagandistic films. For example, in fantasy films where aliens start fighting on the earth and destroy temples and churches in the first place or a meteor falling onto the earth falls onto a temple or church first. This means that the creator of the film is willing to convey the idea to the society that what is named as the House of God is vulnerable and unprotected in reality without any divine powers. All of these refer to iconography which is fighting against images.

Iconography may be of two types: the one used for political events and the other is of the future whose effect may have an impact on the society years after. In order to better perceive iconography of the future, the following example could be drawn from the film " 24 Hours" where the American people got used to the idea of the Afro-American President. This started in 2001 when the film appeared on the media market and its protagonist was an AfroAmerican President of the USA. It is a kind of cultural mythology which creates iconography of the future (Grant, 2007). The positive character created 
in the film had a great influence on the society outlook and after 8 years, in 2009, Americans elected their Afro-American President Barak Obama (See pictures N1 and N2.)

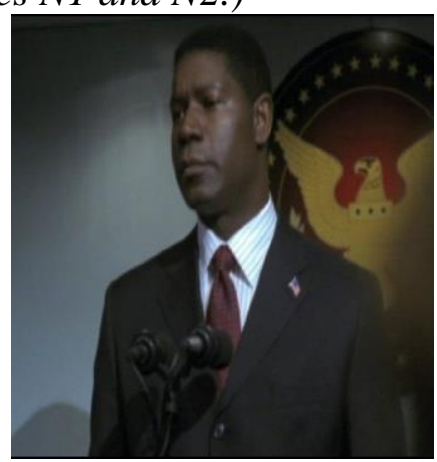

Picture N1. Actor David Palmer

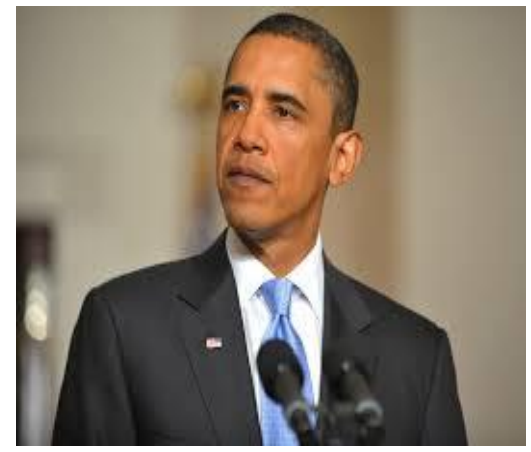

N2. President Barak Obama

It is important to take into cognizance the concept of political iconography. On the one hand, fundamental variables can be trusted in political iconography. On the other hand, potential prospects of extension or transformation of these variables are taken into account (Olesen, 2015). If political iconography is viewed as an object of study which, in its broader meaning, deals with feature imaging of politics, power and communication, the outcome is as expected from the same feature imaging. An example is the transformation of political and cultural identities or manipulation with ideologies or a general control studying that establishes prospects of the concept which can be interpreted as "power". With a broad sense of its meaning, power can be seen as political sovereignty presented in the form of an absolute monarchy or a state. This means that "power" can be perceived as sovereignty and can be accepted as something covering relations between people, e.g., under the meaning of strategic manipulation, which is mainly used by individuals when they lay the foundation of their lives. Furthermore, a question can be formed that can explain the function of power in the context of these changing forms and specific cases, e.g., whether the authorities are rationally interested in the fact that they may become the evidence of those holding the power without any link to their rational function or whether the power and authority can be checked and measured with the same power. Can it serve to solely retain the relations through the existing power? It seems that in each particular case, such reviews change the prospects of representing "power". Irrational authority/power needs an additional noble image since the latter would serve its staging and public communication, while a rational authority/power may be understood through its own image as it can legitimize itself and communicate with its own self in the context of its rational functioning. More so, speaking in general terms, if communication of power serves the purpose of changing/transforming the cultural or political identity, 
then in this context it is naturally important to understand the degree of adequacy to which the subject is developed or how adequately the society is developed for this transformation. It would be absolutely legal if the image of power were discussed as an object for its communication and not as a subject/society receiving the image only. Therefore, the question can be placed even more fundamentally stating that the political iconography of a subject does not start with the idea of his/her (self) establishment but with the pictorial-iconographic representation of his/her politics or authority. Thus, the following questions are asked: what is meant by the image/icon of the word "power"? Does the context of study of political iconography mean prestigious image of a sovereign provided in a creative form, a specific expressive way, gestures or mimic attributes or expressed through photographic scenography of the electoral candidates shown on the posters or digital video records to show a symbolic action of a political representation? What can be considered as political iconography and what is the degree to which the power/authority thus presented is in compliance with its rational context?

Thus, this study attempts to show the importance of the strength of the material and symbolic forms for resolution of difficult situations in the local, national, and global histories and development of power-based relations. According to Gambon, cultural categories such as "an icon/image", "a piece of art", and "an object of culture" coincide with each other and the emblem identity is often versatile and conflicting (Ganguly \& Mandy, 2004). As a result of this, it is necessary to demonstrate the iconographic structure of the Georgian political leaders.

The term "iconography" is used to convey the cultural artefacts of the public culture bearing the form of the authorities that have especially strong influence over both individuals and groups or even the entire society. The twentieth century witnessed many countries under the power of images. The desire to destroy symbols of one power often serves as the means of destroying another power. In order to effectively understand the symbols of power or a problem, images should convey conceivable and in many cases standardized ideas and ideologies that result in intense reactions in the society. Undoubtedly, their role, together with the political meaning is also associated with their destruction implying that they often attract concentrated feelings. Under the Soviet regime, this was the way they used to spread the magnetic charge by collecting people around it and arranging actions (For instance, such magnetic charge can be conveyed through negative information containing a threat to the motherland). During the World War II, the Soviet Authorities, despite the fact that the communism was engaged in a war declared against the Orthodox Christianity at the same time, still used images established over Christian iconography to simply create the overall discourse among the 
society. These images, however, were presented in a different packaging. For example, the picture given below:

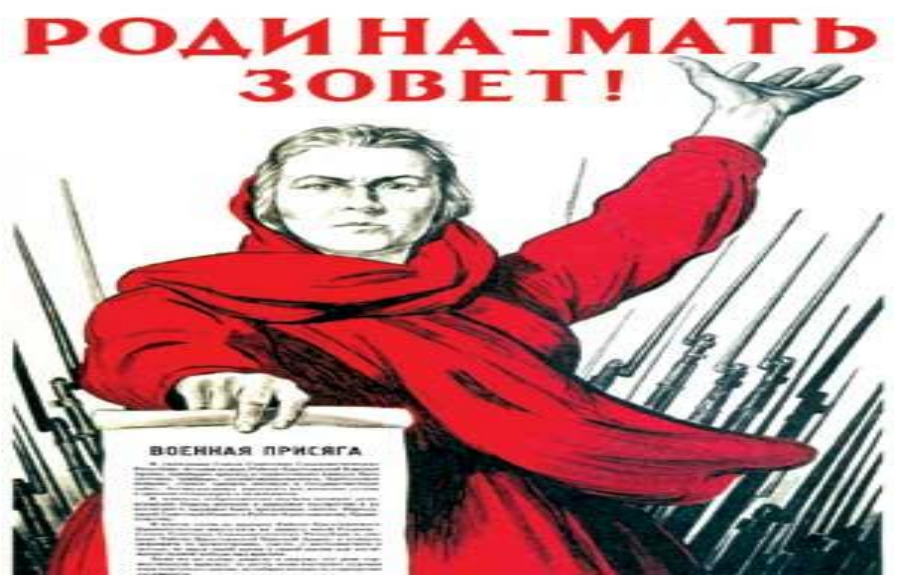

Picture N3. A painting by Irakli Toidze presenting transformation of Christian iconography with a different notion

The poster is built upon an iconography of the Holy Mother and is aimed at public narrative by the Soviet authorities to reach their political goals. A different packaging of the image implies that they created a cult of Mother based upon the iconography of Mother Mary who was calling the people to fight in the war. Iconography holds a special role in the public consumption, has a special place in people's memory, and has social identity and broad political movements. When there is uncertainty in perceiving the meaning/notions, society often uses images to identify the meaning, express it, and make it a public discourse. The image itself had sacred powers for the Orthodox believer. The power of saints, for example, "was thought to be especially concentrated in their icons, sometimes referred to as 'gods' (bogi ), which in time of need or on ritual occasions were used for special blessings" (Ouspensky \& Lossky, 1983). An icon, as a medium for values, is composed of an entire set of public discourses and collective identity, but it also contains a risk of destroying the existing political regime and the established public norms.

Cultures are products created from traditions that form over the course of history. They dictate the terms and conditions for the identity development. On the one hand, identity is built on a culture and develops depending on the mode of life. Actually, it is related to rituals, values, habits as well as actions, social and historical events which influences the history of life and, over the course of time, the system of people's values. On the other hand, culture has its own influence on the main stream of thinking of people depending on their physical environment and the way it has to cope with it (Kaboudarahangi, 2012). These characteristics convey special symbolics and meanings that serve 
the development of a specific identity which will later get established in the culture of people, while the symbolics presents itself with certain semiotic signs that represent symbols showing identity. To a certain degree, integrity of the environment, symbols, and icons create narratives of identity. This means that development of the identity which is dictated by the environment is the foundation for development of the national identity. To make it sound more precise, the identity which is dictated by the environment reflects images of certain individuals and it may be the image of public identity development as well. It is symbolic narratives that the environment takes its notion from presenting itself in the dimensions of poetic imaginations or idiomatics. For this reason, a common meaning obtains a special symbolic connotation that develops into an object of special human sentiments (Riach, 2005).

Iconography which is selected for certain purposes is supposed to reflect the needs, benefits, philosophy, history, and culture of the people who are associated with it through its form, quality, and external appearance. The emphatic iconography used by Mahatma Ghandi to make himself be in the state, live and move as his entire nation, is the best example of this. A closer look at the bellow pictures shows Ghandi in picture N4 who used to study in Britain dressed in the academic style, while the Ghandi shown in Picture N5 is dressed as every Indian on barefoot as the leader of the entire nation.

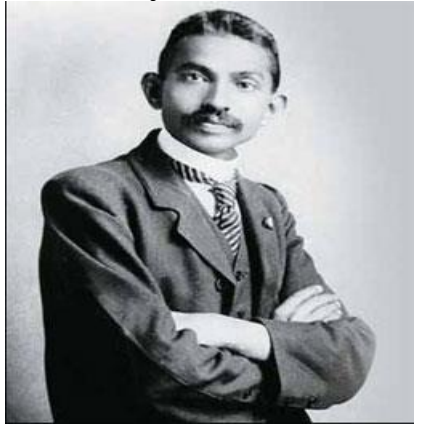

Picture N4

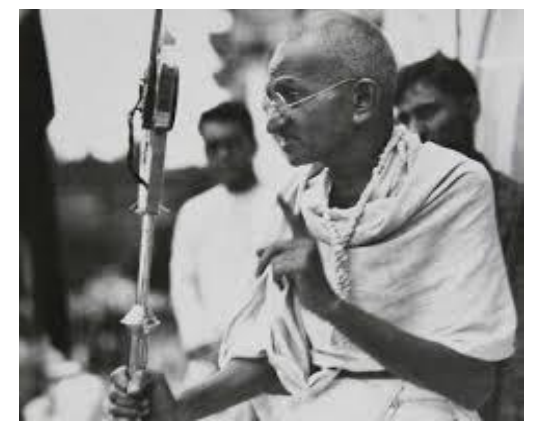

Picture N5

As in other nations, in Georgian public consciousness, the iconography of the hero who is fighting evil is deeply embedded. In Georgia, this iconography is mainly related to the Christian narrative. The concept of martyrdom and hero is of utmost importance for Christian narrative. Martyrdom creates iconic hero in public opinion. Thinking with the iconographic structure is a sustainable moment of Christian religious consciousness. Linking narrative and iconography to each other gives lifesaving power to symbolic thinking (Gogatishvili, 2018). Different epochs and civilizations have different attitude towards death, which is reflected in folklore and literature. Death of a hero is never accidental, and it is the cornerstone in the process of formation of a hero's character. In the world 
literature, we often encounter immortal images of heroes (knights) who achieve perfection and perpetual glory through death. One of Georgians martyred hero is St. George. It is worthy to note that most newborn sons in Georgia are named after St. George. This means that in Georgia, heroic narrative has a very long history in public thinking and any hero and heroic story is related to St. George. This is because his heroism became the example for all heroic activities that existed and will always exist in Georgia. This is the reason why Georgian literature and art is very rich with the icon of a hero, which Georgian society shares from the early age. Thus, this enhances the iconic discourse of a hero. Taking into consideration the iconographic character of Saint George, a lot of works were and are created in Georgian literature, poetry, and folklore. This underlines the importance of a hero for Georgian discourses. For instance, the Battle of Bakhtrioni ${ }^{1}$ where the Georgians defeated the Persians is described by numerous authors. Both spiritual and secular writers often depicted the Battle of Bakhtrioni in their literary works. Anton I of Georgia (Catholicos-Patriarch of the Georgian Orthodox Church) ${ }^{2}$ wrote an extensive work of martyric genre: "Praise to Saint Martyrs Bidzina, Shalva, and Elizbar and the story of their torture". Among secular literary works, the following are noted: Akaki Tsereteli's ${ }^{3}$ Bashi-Achuki, Vazha-Pshavela's s poem, Bakhtrioni and G. Eristavi's ${ }^{5}$ Osetian Story. Apart from this, the folklore also keeps the data about the heroes of this fight (Heroes of Bakhtrioni in Georgian Literature and Folk Speech, 1953). For example, in the Khevsurian ${ }^{6}$ folklore, the heroic theme and motives clearly take leading positions and leading place. The dominant place in Khevsurian poetry takes historical-heroic poetry. Khevsurians call it "a song" which only

\footnotetext{
${ }^{1}$ Battle of Bakhtrioni - the heroic episode of Kakheti rebellion against Iranian conquerors which took place in 1659. The rebellion was headed by Zaal Aragvi Eristavi, his son Zurab, Shalva and Elizbar Eristavis of Ksani and Bidzina Cholokashvili.

${ }^{2}$ Anton I of Georgia (born as Teimuraz Bagrationi on October 28, 1720. Passed away on March 12, 1788) - Georgian church and State figure, Catholicos-Patriarch of East Georgia in 1744-1756 and 1763-1788. Son of the writer and scholar Vakhtang VI's brother.

${ }^{3}$ Akaki Tsereteli (born in the village of Skhvitori, Sachkhere Municipality, on June 21, 1840. Passed away on February 8, 1915) - Georgian poet, writer, publicist, and public figure. He was one of the leaders of the national liberation movement of Georgia.

${ }^{4}$ Vazha-Pshavela (is the pen name of Luka Razikashvili, born in Chargali, present Dusheti Municipality, on July 26, 1861. Passed away on August 9, 1915) - classic of Georgian literature, poet, and writer.

${ }^{5}$ Giorgi Eristavi (was born in Odzisi, present Dusheti Municipality, in 1813. Passed away in Gori on September 9, 1864, and buried in Ikorta Monastery (Upper Ikorta, present Gori Municipality) - playwright, poet, and founder of modern Georgian theatre.

${ }^{6} \mathrm{Khevsureti}$ - historical-ethnographic region in Georgia. It is located in the mountainous region of Eastern Georgia, on the northern and southern slopes of the Caucasus Mountain Range. $42^{\circ} 25^{\prime}-42^{\circ} 27^{\prime}$ of North latitude and $44^{\circ} 48^{\prime}-45^{\circ} 18^{\prime}$ of East longitude.
} 
the motifs created on heroic poems (Gogochuri, 1977). Shota Rustaveli ${ }^{7}$ in his poem titled "The Knight in the Panther's Skin" puts emphasis on the heroism of the characters for the Georgian narrative of all times. The image of the heroin is especially underlined in the poem. A woman can rule the country like men. This is a very progressive opinion announced by the viziers:

"Though indeed she be a woman, still as sovereign she is begotten of God. She knows how to rule. We say not this to flatter you; we ourselves, in your absence, often say so. Her deeds, like her radiance, are revealed bright as sunshine. The lion's whelps are equal (alike lions), be they male or female" (Tsulukidze Al, 1966).

Considering that literature, poetry, and folklore form cultures in communities and develop narrative and general discourse, it can be said that the martyrdom of Saint George, his heroism as well as the depiction of the deeds of different heroes encouraged establishment of heroic narrative in Georgian literature. Heroes are strong and good warriors distinguished for their chivalry fight while sacrificing themselves. They always gained victory over evil. It can be said that the iconography of the hero is ideal for Georgian public consciousness, whose image consistently actualizes in the actions of political subjects. This is why every politician who intends to rule the country tries to create the image of a martyred and savior hero.

Thus, all three Georgian presidents used political iconography but each of them did it in different ways. However, they had one thing in commonthe iconography brought them to success and failure as well. Zviad Gamsakhurdia, for instance, came to politics with the image of a savior, using the word "freedom" as a code and people were ready to accept the message (Hall, 1999). At the first stage, the President's reputation was destroyed when his authorities exercised pressure over the media since controlling the media conflicted with the coded word "freedom". At the second stage, the society did not accept active involvement of the first lady in politics at that time. This refers to the political announcements made by Manana Archvadze Gamsakhurdia - the wife of the President. The third and the last stage was the destruction of the iconography of a hero, when the hero was found to be shut in an underground shelter together with his supporters asking people for help. Politicians are not supposed to ask their supporters for help. On the contrary, supporters expect their hero to help them. Iconography continues to live in Zviad Gamsakhurdia as in a martyr and not as in a hero or a savior. As for the political iconography of Eduard Shevardnadze, at the first stage, he was the politician who was unconquerable, powerful, and almighty. Destruction of his

\footnotetext{
${ }^{7}$ Shota Rustaveli, Rustveli (*approx. 1160/65 - ? ) - XII century great Georgian poet and thinker, and the author of the well-known poem "The Knight in the Panther's Skin". Many literary critic consider him to be one of the most important representatives of the medieval world literature.
} 
political iconography, which was his almightiness, started with the extreme financial crisis, the utmost hardship of people, and the fact that Georgia was a feeble geopolitical player. All this saw its continuation in the course of democracy. This is because being a leader of a democratic country and having an image of a powerful undefeatable politician are two notions that should not exist at the same time. Democracy is ensued by both political criticism and satire. This brings forth brave people who, in Georgia, managed to make security guards remove a frightened politician from the legislative body. As for the third president and his political iconography, it all started successfully and the iconographic image of Mikheil Saakashvili was that of a politician equipped with western values who defended human rights. However, the fact that human rights are given much attention in the penitentiary system means that Mikheil Saakashvili's political iconography was created by human rights and the violation of the same rights destroyed his iconographic image.

As mentioned earlier, formation of iconographic structure of Zviad Gamsakhurdia as a leader was highly influenced by the public narrative of his time as well as the common discourse claiming that a leader should have "good family roots". Zviad Gamsakhurdia was born in Tbilisi on March 31, 1939, to the family of a Georgian writer and public figure Konstantine Gamsakhurdia and Miranda Palavandishvili (Jgerenaia, 2017). This factor fully satisfied the requirements the society had those days. Zviad Gamsakhurdia's image and his political steps happened to be successful and acceptable for the society because Georgia and all the states formerly united under the Soviet Union which followed the anti-Soviet course. In 1956, Zviad Gamsakhurdia and his friends spread political leaflets in the streets of Tbilisi and disapproved the blood-shedding intervention of the Soviet Union into Hungary. This was something not seen throughout the entire USSR. In 1976, Zviad Gamsakhurdia and Merab Kostava set up Helsinki Group of Georgia, and Zviad Gamsakhurdia chaired the organization till the very last day of his life. Helsinki Group took active measures to defend human rights and the rights of the Georgian nation in the first place. They also strived to protect the Georgian cultural monuments and the Georgian Orthodox Church. The group published underground magazines such as "Georgia", "Golden Fleece", "Georgian Broadcaster", etc. The issuing of these magazines was initiated by Zviad Gamsakhurdia (Jgerenaia, 2017). With the support gotten by these measures, Zviad Gamsakhurdia managed to create a political iconographic image that was acceptable for the Georgian society which was powerful at the same time. The end of his political iconography began with the attack his team exercised over the media. Zviad Gamsakhurdia was associated with the politician supporting free media before he became the president. During his presidency, the opposing paper "Molodyozh Gruzii" was closed upon his order under the pretext that the paper was used to openly call for national opposition. Giorgi 
Chanturia, whose National-Democratic Party was one of the most active opposing parties at that time, was arrested and accused of searching for help in Moscow to overthrow the legitimate government. There were pieces of information spread concerning closing Channel II of the Georgian TV as well, as its employees participated in the street riots held against the government (Jgerenaia, 2017). Zviad Gamsakhurdia's attitude towards protection of human rights before he became the president was contrary to the drastic measures taken by him and his team toward the ethnical minorities living in Georgia (who used to form approximately $30 \%$ of the Georgian population). This calls for attention and needs to be considered. Although one part of the group created out of the mentioned minorities took an active part in resurrection of democracy in Georgia as a result of the elections held in October 1990, they were given only 9 seats out of the 245 in the Parliament. The issue of the national minorities was problematic even before the announcement of the independence of the country. This was followed by serious ethnic oppositions in Abkhazia in 1989. The fact that the motto of one part of Gamsakhurdia's supporters during the electoral campaign was "Georgia for Georgians" aggravated the situation further (Lasswell, 1951). Hence, the main mistake made by Zviad Gamsakhurdia was that he created his political iconography not for all the citizens living in Georgia but for Georgians only. The most powerful element of the political iconography of President Gamsakhurdia was the image of him as a savior, saint warrior, and a hero for people which was created by his political acts. This started with the dissident movement directed against the Soviet regime and finished with the declaration of the independence of Georgia (Grotowski, 2010). Gamsakhurdia, as the political hero, gave to Georgian people what had been unimaginable for everyone and this was the independent Georgian state. Iconography of Gamsakhurdia, as a hero and savior, came to its end point when he and his team turned out to be besieged and started defending themselves. It was unexpected to see the iconography of a hero and savior that had been enrooted in the minds of people in the situation of a helpless unprotected man. On January 6, Gamsakhurdia and the members of his government managed to leave the besieged building and fled to Azerbaijan, even though they were not given the desired shelter there. Armenia accepted him for a short time and denied his extradition to Georgia. Pursuing the goal of avoiding deterioration of the strained relation with Georgia, the government of Armenia allowed Gamsakhurdia to flee to Chechnya, a separatistic region of Russia, where the government of Jokhar Dudaev provided shelter to him (Jgerenaia, 2017). It is also worthy to note that the political iconography of President Gamsakhurdia was so powerful that it had its influence over people not only during the life of the president, but also after his death. If the president created an iconography of a hero and savior for people, the latter created an 
iconography of the president as a martyred hero. The government of Georgia announced the death of President Gamsakhurdia on January 5, 1994. However, some of his supporters refused to believe it until he was found dead on February 15, 1994. Zviad Gamsakhurdia was buried in Grozno on February 24. On March 3, 2007, the newly elected President of Chechnia Ramzan Kadirov declared that the grave of Zviad Gamsakhurdia that had been lost during the wars in Grozno was found in the city center. Identity of Gamsakhurdia's corpse was proved by Russian experts in Rostov-on-Don. On March 28, 2007, it was brought to Georgia (Jgerenaia, 2017). We might say that the image of the political iconography of President Gamsakhurdia is still alive for his supporters and opposers.

Unlike Zviad Gamsakhurdia, Eduard Shevardnadze could not manage to create an image of the political iconography of a hero or a savior of himself, neither did the society create a political iconography of him as a martyred politician. Nevertheless, from the very day he came into politics, he tried to create a political iconography of himself as an almighty and undefeatable politician both among the global political society and within Georgia (supporting the political meeting held in 1978 to defend the Georgian language, retaining emotional sustainability during the attacks in 1992, 1995, and 1998). He demonstrated an outstanding synthesis of the characters of the "Lion" and the "Fox" that Niccolo Machiavelli (1469-1527) thought to be essential for a politician. He was blessed with abundance of traits that Machiavelli called "virtù" or virtue. From the political viewpoint, he called it "power", "bravery", and "hardworking/daring character" (Machiavelli, 1995). "White Fox" was the nickname given to Shevardnadze in the diplomatic circles. This name which later became very popular among people was an exact word to describe his political portrait. In the attempt to name virtues of Eduard Shevardnadze, the main one he had was that he had no inner life at all. If he still had one, it was totally invisible and unfamiliar to people (Jgerenaia, 2017). However, despite his iconographic image as an undefeatable and power politician, Shevardnadze never collided into a wall upon his own political decision and was never found in a dead-lock situation. He always considered specific cases and circumstances when making a political step or a political announcement. For instance, in 1976, at XXV assembly of the USSR Communist Party, Eduard Shevardnadze, the First Secretary of the Central Committee of the Communist Party of Georgia, pronounced the following words: "Comrades, Georgia is called a sunny country, although our real sun has risen not from the east, but from the north - from Russia., it was the sun of the Leninistic ideas. Georgia is a warm southern republic, though the real warmth has come to us from the north - the Dariali Gorge." Nonetheless, years passed and the author of these words in one of his interviews said: "By 2005 approximately, or by the end of my presidential term, we will be knocking on 
the NATO's doors" (Jgerenaia, 2017). The very west-bound course chosen by him happened to destroy his political iconography demonstrated by an image of a powerful and almighty politician. This is because establishing the western standards in the state and maintaining the image of an almighty politician at the same time proved to be impossible. The western political requirements imply free media and freedom of speech which qualitatively ruins leaders and leading figures. Attenuation of Eduard Shevardnadze's iconography started with democracy and ended with the process accompanying democracy involving freedom of speech and expression of opinions/ideas. Thereafter, the security guard ensured that the undefeatable leader was removed immediately from the eyes of people. The main reason was that Shevardnadze was a politician formed by another system. Therefore, he could not manage to build a new Georgian state. This is in line with the popular saying that the "old vessel" cannot contain "new wine". The policy of balance that he pursued looked very much like rocking a cradle, and "rocking a cradle" caused people to fall into an almost lethargic sleep which was full of nightmares (Jgerenaia, 2017). At the same time, it can be said that one part of the political iconography created by Shevardnadze, the one which was never spoken about loudly by him but was well known to everyone and dearly cherished by him, was his family. His family was the most secure place for him. This explains the fact when at the end of his career (November 23, 2003) he was asked by a journalist: "Where are you going to, Mr. Shevardnadze?" He replied in a calm manner: "Home!" (Jgerenaia, 2017)

Mikheil Saakashvili's political iconography was different from that of Eduard Shevardnadze. However, the iconographic image created by Mikheil Saakashvili coincides with that created by Zviad Gamsakhurdia in two aspects: the images of a savior and hero. Until the Rose Revolution, the country was in a very hard economic situation. As a result of this, the public who saw its savior and hero in Zviad Gamsakhurdia who was embarking on the path of freedom and independence also identified the same figures in Saakashvili now embarking on the road of the country's development. The political demonstration which was attended by thousands of people was crowned with the Rose Revolution. On November 22, Saakashvili personally led the people following him into the parliament building to wreck the first session of the newly elected Parliament of Georgia and to end it all with the resignation of Shevardnadze on November 23. Mikheil Saakashvili, who was one of the most popular leaders of the revolution, happened to be the only real candidate to be considered in the earlier parliamentary elections. In the elections held on January 4, Saakashvili got 96, which was $27 \%$ of the votes. After the inauguration ceremony held on January 25, he became the President of Georgia. He created an iconography of a hero struggling against the authoritarian regime which was fighting against Shevardnadze and also 
opposing Aslan Abashidze. This was the medium through which the Georgian politics acquired a new iconographic image of a person fighting for freedom of speech, protection of human rights, and establishing democracy. Moreover, President Saakashvili perfectly fits into the image of a young and pro-Western politician. This was strengthened by the May 10, 2005, visit to Georgia of the US President George Bush. The iconography of a hero and savior of the person struggling against an authoritarian leader and fighting for protection of human rights was ruined in November 2007. In autumn of 2007, Saakashvili's rating fell. In October of the same year, there were a few protesting demonstrations held against his ruling. This was followed by political actions of November 27 organized by the united opposition and a businessman, Badri Patarkatsishvili. The protesting political actions ended on November 7 through dispersal of the Protestants by the police and intrusion of the police forces into the opposition TV channel offices. Thereafter, Saakashvili announced the state of emergency. The political iconography created by Mikheil Saakashvili finally collapsed in 2012 through publishing the video recordings made in the penitentiary system that demonstrated inhuman attitude and torturing of the convicts. It is also important to mention that the third President of Georgia has maintained his image of a pro-Western politician up till today, while the legal foundation to all of this was laid by him on March 13, 2007. The main priority of Saakashvili's external politics was for Georgia to become a NATO member. The same was proved by the Parliament of Georgia with its resolution adopted on March 13, 2007, as well as by the plebiscite of 2008.

\section{Conclusion}

Based on the examples analyzed in this study, political iconography and created iconographic images and icons are of utmost importance both for the globally acting politicians and those acting in Georgia. It also has a great influence over the society. Also, based on the political iconographic analysis of all three presidents of Georgia, it can be said that all three leaders studied the common discourse of the time that rose out of the Georgian public notions. This was successfully employed by all three presidents at the initial stage in pursuance of the creation of successful political careers. Zviad Gamsakhurdia managed to destroy the iconography of a Soviet politician. At the same time, he also created an iconographic image of a hero and savior of himself. However, Eduard Shevardnadze destroyed the iconography of a hero and savior and rather offered people the iconography of a powerful and almighty politician which was fought against and destroyed by Mikheil Saakashvili. Throughout his career, he offered his political iconography not as an almighty but as a democratic leader. Nevertheless, all three political figures had their political iconographies that brought them to politics and made them leave it as well. At the end, analyzing political iconography draws a conclusion that if 
the goal of all three analyzed persons was to destroy each other's iconographies, the last years showed a leader (Bidzina Ivanishvili) who appeared in the Georgian politics for a short period who tried to destroy the iconographies of all these three images in the eyes of the public as well as to destroy the phenomenon of team management/governing.

\section{References:}

1. Aris, A. \& Bughin, J. (2009). "Managing Media Companies" Pp. 312.

2. Ganguly, D. \& Mandy, T. (2004). Cultural Politics and Iconography: An Introduction. Pp.1-6. Humanities Research Vol. XI No.1.

3. Gaprindashvili, N. (2015). Fundamentals of Rthetorics. Pp.132. Publishing House Nekeri, Tbilisi. [In Georgian]

4. Gogatishvili, M. (2018). Christian Iconography of Free Art. The Mission of a Modern University. Tbilisi. P. 132. [In Georgian]

5. Gogochuri, D. (1977). Khevsurian Heroic Poetry and Characters. Tbilisi, "Ganatleba". P. 184. [In Georgian]

6. Grant, B. K. (2007). Film Genre. From Iconography to Ideology. Pp. 131. First published in Great Britain.

7. Grotowski, P.L. (2010). Translated by Richard Brzezinski Arms and Armor of the Warrior Saints Tradition and Innovation in Byzantine Iconography (843-1261). Brill Leiden Boston.

8. Groys, B. (2014). Essays. Pp. 170. Ilia State University Publishing, Tbilisi. [In Georgian]

9. Hall, S. (1999). Encoding, Decoding. pp.507-517. The Cultural Studies Reader Second Edition Edited by Simon During. Second edition. Routledge. London and New York.

10. Heroes of Bakhtrioni in Georgian Literature and Folk Speech (1953). Academy of Sciences of the Georgian SSR. Tbilisi. P. 44. [In Georgian]

11. Jgerenaia, E. (2017). - Zoon Politikon Details for Eduard Shevardnadze's Portrait, Pp. 24-41. Journal. Politics. N 3 Tbilisi. [In Georgian]

12. Kaboudarahangi, M., Mohd Tahir, O., \& Kamal, M. (2012). M.S. Iconographic Method and The Development of Emerging garden's Identity. pp. 3724-3730 Journal of Basic and Applied Scientific Research. J. Basic. Appl. Sci. Res., 2(4)

13. Laswell, H. D. (1951). The Political Writings. Pp.525. By The Free Press a corporation. Illinois.

14. Machiavelli, N. (1995). The Prince. Edited and Translated By David Wootton. Hackett Publishing company. Indianapolis/Cambridge. 
15. Malaghuradze, T. (2013). Modern Theories and Concepts of Mass Communication Pp. 290. (Supplementary textbook), Publishing House Universal, Tbilisi. [In Georgian]

16. Mnemosyne (2006). Students' Works in Elinology and Latin Studies. N2. Tbilisi. [In Georgian]

17. Olesen, T. (2015). Political Iconography. Global Injustice Symbols and Social Movements. Pp. 37-65 Palagrave. Mcmilan.

18. Ouspensky, L. \& Lossky, V. (1983). The Meaning of Icons, trans, G. E. H. Palmer and E. Kadloubovsky (Crestwood, New York,).

19. Riach, A. (2005). Representing Scotland in Literature, Popular Culture and Iconography. Pp.280. Palgrave Macmillan. St. Martin's Press.

20. Tsulukidze, Al. (1966). Works of Kutaisi State Pedagogical Institute. Vol. XXIX. Dedicated to Shota Rustaveli's 800th anniversary. Kutaisi. P. 382. [In Georgian] 